\title{
Cell-free DNA in Human Follicular Fluid as Biomarker for Intracytoplasmic Sperm Injection Procedure Outcome
}

\author{
Maanee Azzam* (D), Adeela Hamood² ${ }^{1}$, Hind Abdulkadim³ \\ ${ }^{1}$ Department of Gynecology, Kamal Al-Samari hospital, Ministry of health of Iraq, Baghdad, Iraq; ${ }^{2}$ Department of Gynecology, \\ Ministry of Health, Local Arab Council for Health Specializations, Baghdad, Iraq; ${ }^{3}$ Department of Urosurgery and Infertility, \\ College of Medicine, University of Kufa, Kufa, Iraq
}

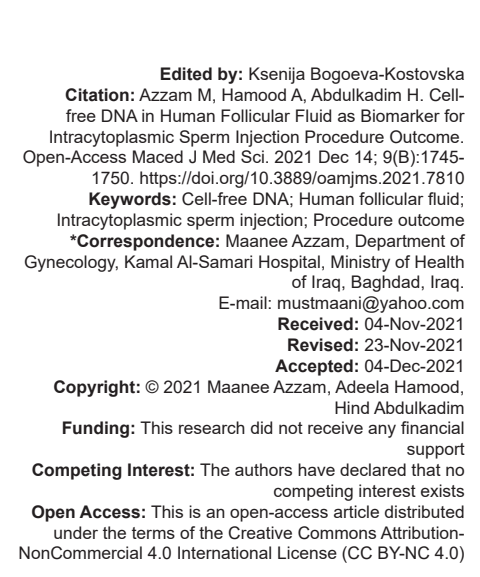

Abstract

BACKGROUND: Follicular fluid (FF) is considered as an important microenvironment for oocyte development. Cellfree DNA (cfDNA) fragments that are found in this fluid and are released from cell apoptosis and/or necrosis.

AIM: This study aimed to quantify the level of cfDNA, in the FF, and to assess any relationship between the level of cfDNA in this fluid with women's age, duration of infertility, cause of infertility, and her ovarian reserve values.

METHODS: Eighty-nine women were prospectively included in this study FF cfDNA, which was determined by conventional real-time PCR-SYBR green detection approach which quantified by ALU-specific primers.

RESULTS: Cell-free DNA (cfDNA) level in FF samples of Iraqi women level was cfDNA (Mean \pm SD $0.916 \pm 0.106 \mathrm{ng} / \mathrm{\mu l})$. There was no significant relation between cfDNA and pregnancy outcome, but very low level and very high level cfDNA were related to negative pregnancy outcome, cfDNA was the second most important predictive factor of pregnancy outcome after fertilization rate, but both not statistically significant $p$-values were 0.622 and 0.241 , respectively.

CONCLUSION: The present study notices that cfDNA in the FF may mainly reflect the cellular activity and the balance between programmed apoptosis and cell necrosis.

\section{Introduction}

Despite the advancement in treatment techniques, infertility remains a struggle for many doctors to treat couples in their reproductive years. Many doctors prefer a single embryo transfer as an important step in the management, but the selection methods for the embryo with the highest chance for implantation still rely on embryo morphology alone; however, there are limitations to these evaluations and selections [1], [2]; researcher focused on non-invasive biomarkers based on oocyte microenvironment studies to upgrade embryo selection process [3]. New "omics" technology includes biomarkers and assays for oocyte and embryo selection in vitro fertilization (IVF/ICSI). It is a new procedure that depends on different body fluids and tissues, genomics, transcriptomics, proteomics, and metabolomics [4], [5]. How uses follicular fluid (FF) produced from plasma with a product from granulosa cells. It is significant since it is the environment, in which the oocyte grows [2], [6]. The oocyte is the functional unit of the ovary, surrounded by somatic cells, which are the granulosa cells. It is the female gamete (germ cell) that is participating in the fertilization process. The environment for oocyte growth is FF produced from plasma and contains factors secreted by granulosa cells (Gc). It is used as a non-invasive practical method for predicting oocyte quality in assisted reproductive techniques [7], [8]. The most recent method in IVF is a genomics analysis of cell-free DNA (cfDNA). Mandel and Metais discovered the cfDNA in the body's tissues and fluids in 1948 and named it cfDNA (cell-free DNA). It also included extracellular DNA molecules, such as those present in serum, plasma, and other body fluids [9], [10]. DNA was shown to be the inheritance's material byWcatson and Crick in 1953, the researchers demonstrate its presence in the plasma of healthy and ill individuals [11]. These discoveries enhanced scientists in other fields, who began looking for non-host DNA in the plasma and serum. Lo et al. in 1997 first reported that the existence of fetal derived $Y$ chromosomal DNA sequence in maternal circulation [12] was initially reported by which later made a non-invasive prenatal testing feasible and early given the high detection rate for trisomy 21 [13]. It has recently been shown that it is also higher among people who have pre-eclampsia, pre-term labor, and other complications during pregnancy [14], [15]. Scientists are looking into the existence of cfDNA in several fields of reproductive medicine, the levels of plasma cfDNA during ovarian 
stimulation, as well as the relationship between cfDNA concentration and pregnancy rates in women undergoing IVF-embryo transfer were investigated in several prospective studies [16]. Moreover, these studies discovered that plasma cfDNA levels were higher in women who did not conceive than in those who did, and the author linked this finding to the presence of factors that may interfere with the embryo implantation, as a result, they decided that cfDNA analysis in individual FF samples could be a useful biomarker for predicting the best quality embryo [2], [5] cell-free DNA: Are circulating free cell DNA are degraded DNA fragments which are non-capsulated genetic materials, cfDNA refers to nuclear or mitochondrial DNA fragments. Nuclear strands are typically 150-180 base pairs (bp) in length, have an average half-life of fewer than $2 \mathrm{~h}$, where macrophages rapidly phagocytized it in healthy individuals who have a low level of cfDNA [17], [18]. Its formation is most likely related to one of three events: Apoptosis, necrosis, and active secretion. Healthy people get their cfDNA primarily from apoptotic cells, which are considered the principal source of this cf-DNA as there is $50-70$ billion cells die via programmed cell death. These cells are primarily phagocytosed by macrophages shortly after being released into circulation. This cfDNA can be quantified in the FF and investigated as a non-invasive simple method to qualify the oocyte's microenvironment and predict the success of treatment in the ICSI cycle [19], [20]. In this study, we aimed to quantify the level of cfDNA, in the FF, and to assess any relationship between the level of cfDNA in this fluid with women's age, duration of infertility, cause of infertility, and her ovarian reserve values then we searching to found any relations between the types of protocol, several oocytes, embryos, and success of ICSI outcomes by assessing the clinical pregnancy results. Trying to find a new non-invasive parameter that may reflect the oocyte microenvironments development and that reflects the quality of oocytes and can expect the response to the stimulation, quality of embryo developed. Moreover, see whether this new parameter may improve the infertility treatments and results.

\section{Materials and Methods}

In this prospective study, the data from 89 patients undergo in vitro fertilization cycles conducted at the Reproductive Medical Centers for Fertility and IVF cycle, in High Institute of Infertility Diagnosis and Assisted Reproductive Technologies, Al-Nahrain University, and AL-Nada IVF private center (Baghdad/Iraq), between October 2020 and August 2021, under the supervision of consultant genetic researchers from Forensic DNA Center for Research and Training (AL-Nahrain University). After informing the participants about the objectives and methods, their consent was obtained on the day of oocyte retrieval. Arab Focality approved this study for medical specialization. The patient's characteristics are detailed in Table 1. Women ages ranged from 19 to 42 years (Mean \pm SD $30.9 \pm 6.1$ ), their body mass index (BMI) was between 19 and 33 (Mean \pm SD $25.96 \pm 3.48 \mathrm{~kg} / \mathrm{m}^{2}$ ), and infertility duration 1-17 years (Mean \pm SD $6.9 \pm 4.4$ ). Cause of infertility was a malefactor in $30.3 \%$, hormonal assessment in day 3 of the cycle, and AFC evaluated day 5 of the cycle. Patients received standard ovarian stimulation with recombinant FSH ( $r-F S H)$, two methods are used either under pituitary suppression with a $\mathrm{GnRH}$ agonist, the $\mathrm{GnRH}$ agonist (Decapeptyl $0.1 \mathrm{mg}$ Ferring, Kiel Germany) subcutaneously in the midluteal phase of the previous cycle usually day [21], with a daily dose, after check pituitary desensitization then ovarian stimulation was achieved by administration of 150-225 IU/day of r-FSH (Gonal-F, Merck Serono SA Aubonne Branch, Swiss Confederation). FSH was administered on an individual basis according to the

Table 1: The demographic and biochemical features of the study group

\begin{tabular}{|c|c|c|c|c|}
\hline Variable & No. & $\%$ & Mean \pm SD & Range \\
\hline \multicolumn{5}{|l|}{ Wife age (years) } \\
\hline$<20$ years & 1 & 1.1 & \multirow[t]{4}{*}{$30.9 \pm 6.1$} & \multirow[t]{4}{*}{$19-43$} \\
\hline $20-29$ & 37 & 41.6 & & \\
\hline $30-39$ & 42 & 47.2 & & \\
\hline$\geq 40$ years & 9 & 10.1 & & \\
\hline \multicolumn{5}{|l|}{ BMI $\left(\mathrm{kg} / \mathrm{m}^{2}\right)$} \\
\hline Normal (18.5-24.9) & 34 & 38.2 & \multirow[t]{3}{*}{$25.96 \pm 3.48$} & \multirow[t]{3}{*}{$19-33$} \\
\hline Overweight (25-29.9) & 47 & 52.8 & & \\
\hline Obese $(\geq 30)$ & 8 & 9.0 & & \\
\hline \multicolumn{5}{|l|}{ Duration of infertility } \\
\hline$<2$ & 4 & 4.5 & \multirow[t]{3}{*}{$6.9 \pm 4.4$} & \multirow[t]{3}{*}{$1-17$} \\
\hline $2-4$ & 27 & 30.3 & & \\
\hline$\geq 5$ years & 58 & 65.2 & & \\
\hline \multicolumn{5}{|l|}{ Cause of infertility } \\
\hline Endometriosis & 8 & 9.0 & & \\
\hline $\begin{array}{l}\text { Hypogonadotropic } \\
\text { hypogonadism }\end{array}$ & \multicolumn{3}{|c|}{ hypogonadism } & \\
\hline Male & 27 & 30.3 & & \\
\hline Mixed & 10 & 11.2 & & \\
\hline $\mathrm{PCOS}$ & 6 & 6.7 & & \\
\hline Poor reserve & 12 & 13.5 & & \\
\hline Tubal & 11 & 12.4 & & \\
\hline Unexplained & 12 & 13.5 & & \\
\hline \multicolumn{5}{|l|}{ First ICSI } \\
\hline Yes & 31 & 34.8 & & \\
\hline No & 58 & 65.2 & & \\
\hline \multicolumn{5}{|l|}{ Type of protocol } \\
\hline Antagonist & 83 & 93.3 & & \\
\hline Agonist & 6 & 6.7 & & \\
\hline \multicolumn{5}{|l|}{$\mathrm{FSH}(\mathrm{U} / \mathrm{L})$} \\
\hline$<10$ & 76 & 85.4 & $6.57 \pm 3.06$ & $0.10-16.3$ \\
\hline$\geq 10$ & 13 & 14.6 & & \\
\hline \multicolumn{5}{|l|}{$\mathrm{LH}(\mathrm{U} / \mathrm{L})$} \\
\hline$<3$ & 13 & 14.6 & $7.79 \pm 8.31$ & $0.10-35.9$ \\
\hline $3-5$ & 38 & 42.7 & & \\
\hline$>5$ & 38 & 42.7 & & \\
\hline \multicolumn{5}{|l|}{$\mathrm{AMH}$} \\
\hline$\leq 1$ & 26 & 29.2 & $2.04 \pm 1.34$ & $0.24-7$ \\
\hline$>1$ & 63 & 70.8 & & \\
\hline \multicolumn{5}{|l|}{$\mathrm{AFC}$} \\
\hline$<10$ & 28 & 31.5 & $13.28 \pm 7.14$ & $3-38$ \\
\hline \multirow{2}{*}{\multicolumn{5}{|c|}{17 b-estradiol (E2; pg./ml) }} \\
\hline & & & & \\
\hline$<1000$ & 30 & 33.7 & $1459.0 \pm 805.3$ & $236.1-$ \\
\hline 1000-2000 & 40 & 45.0 & & 3500 \\
\hline$>2000$ & 19 & 21.3 & & \\
\hline Prolactin & & & $20.85 \pm 11.73$ & $1.2-56.66$ \\
\hline TSH & & & $1.97 \pm 0.99$ & $0.51-6.00$ \\
\hline Peak E2 level (pg./ml) & & & $40.14 \pm 19.07$ & $1.0-87.97$ \\
\hline \multicolumn{5}{|c|}{ Duration of stimulation (days) } \\
\hline $7-10$ & 23 & 25.6 & $11.1 \pm 1.3$ & $8-13$ \\
\hline$>10$ & 66 & 74.4 & & \\
\hline Total dose & & & & \\
\hline$<3000$ & 58 & 65.2 & $2487.3 \pm 780.4$ & $800-4500$ \\
\hline$\geq 3000$ & 31 & 34.8 & & \\
\hline
\end{tabular}

follicle count, E2: 17 b-estradiol, TSH: Thyroid-stimulating hormone. 
ovarian response, assessed by sequential transvaginal ultrasonography and serum estradiol measurements. Or using the $\mathrm{GnRH}$ antagonist program, by a starting daily dose of 200-225 IU, rFSH (Gonal F Merck Sernono, or Follitrope LG Life Science) was started on day 2 of the menstrual cycle, women received the $\mathrm{GnRH}$ antagonist cetrorelix acetate (Cetrotide; Asta Medica AG, Frankfurt, Germany) at a dose of $0.25 \mathrm{mg} /$ day from the day when the dominant follicle reached a mean diameter $\leq 14 \mathrm{~mm}$ until the day of HCG administration. In the stimulation period, rFSH daily dose was adjusted individually. In all groups, the trigger of the oocyte by either Ovitrelle $250 \mu \mathrm{g} / 0.5 \mathrm{ml}$, Merck Serono S.P.A-Italy, or Pregnel (HCG) 5000 iu/ampMSD, both adjusted according to the BMI of patients, in patients with a high risk of OHSS trigger done by decapeptide $(0.2 \mathrm{mg}) \mathrm{SC}$, to avoid OHSS, oocyte aspiration was performed (35-36 h) after HCG injection. Intracytoplasmic sperm injection was performed using standard procedures and the embryos were transferred 3-5 days later. Maturation and morphological features of oocytes were investigated immediately before ICSI, fertilization rate, early embryo development, and transfer were documented and studied. All FF samples were collected from the patients with clear appearance, $10 \mathrm{ml}$ was centrifuged for $10 \mathrm{~min}$ at $3000 \mathrm{~g}$, later on, filtered with $0.45 \mu \mathrm{m}$ filters paper then stored at $-8^{\circ} \mathrm{C}$, until all collected samples were completed and ready to analyzed cfDNA. Fertilization of oocyte which is then cultured in universal IVF media (Orogio, Denmark), the fertilization $18 \mathrm{~h}$ examined, and on days $2-3$. On days $4-5$, quantitative of ALU repeats: Cell-free DNA extraction and quantification by ALUqPCR FF pools were prepared for cfDNA quantification as previously reported [20]. We use gSYNC (DNA) Extraction Kit, with a cat. No. GS100 and Lot No. FG32501 (Geneaid company). Add $400 \mu$ of W1 buffer to the GS Colum and put the tube in a centrifuge at $14,000 \mathrm{~g}$ for $30 \mathrm{~s}$, discard the flow-through, place the GS Colum. Add $600 \mu \mathrm{l}$ of wash buffer and put the tube in a centrifuge for $30 \mathrm{~s}$ discard the flow-through, put the tube in a centrifuge without adding any buffer because dry the tube, take 30 for ELUTION buffer to GS Colum and let stand for at least $3 \mathrm{~min}$, and put the tube in a centrifuge at $14,000 \mathrm{~g}$ for $1 \mathrm{~min}$, elute the purified DNA. The total cfDNA was quantified by qPCR, using ALU 115 primers. Each ALU-qPCR reaction included $1 \mu \mathrm{L}$ of PK-digested FF pool and a reaction mixture containing $0.25 \mu \mathrm{M}$ of forward and reverse ALU 115 primers and $5 \mu \mathrm{L}$ of 2X LightCycler480 SYBR Green I master mix (Roche Applied Science, Germany). CfDNA concentration in FF pools was determined using a standard curve obtained by successive dilutions of genomic DNA [21]. A negative control (without template) was integrated into each qPCR plate and each FF pool was analyzed in quadruplicate. To determine which proportion of cfDNA was released from necrotic or apoptotic cells, cfDNA was also quantified using qPCR with ALU 247 primers. These primers amplify only larger fragments that result from necrosis. This allows the calculation of DNA integrity using the Q247/Q115 ratio [21], which represents the proportion of cfDNA generated by necrosis over total cfDNA. The mean of Q247/Q115 ratio in FF was cfDNA (Mean $\pm S D, 0.91 \pm 60.106 \mathrm{ng} / \mu \mathrm{l}$ ), suggesting that the cfDNA analyzed mainly originated from cellular apoptotic events.

Statistical analysis of data was carried out using the available statistical package of SPSS-27 (Statistical Packages for the Social Sciences - version 27). Data were presented in simple measures of frequency, percentage, mean, standard deviation, and range (minimum-maximum values).

The significance of the difference of different means (quantitative data) was tested using Student's t-test for the difference between two independent means or the ANOVA test for difference among more than 2 independent means. The significance of the difference of different percentages (qualitative data) was tested using the Pearson Chi-square test ( $\chi^{2}$-test) with the application of Yate's correction or Fisher's exact test whenever applicable. Statistical significance was considered whenever $p \geq 0.05$ was considered. Receiver operating characteristic "ROC" curve technique was used to determine the use of any parameter as diagnostic or screening tool for disease and the ability to determine the "cutoff value" which of optimum sensitivity and specificity for diagnosing disease.

\section{Results}

Table 1:

The patient's characteristics are detailed in

The reference level of cell-free DNA in the participant Iraqi women and its quantitate measured in $89 \mathrm{FF}$ samples showed that its concentrations are varied from 0.676 to $1.401 \mathrm{ng} / \mu \mathrm{l}$. Figure 1 clearly shows frequent distributions values lie between 0.8 and $0.9 \mathrm{ng} / \mu \mathrm{l}$.

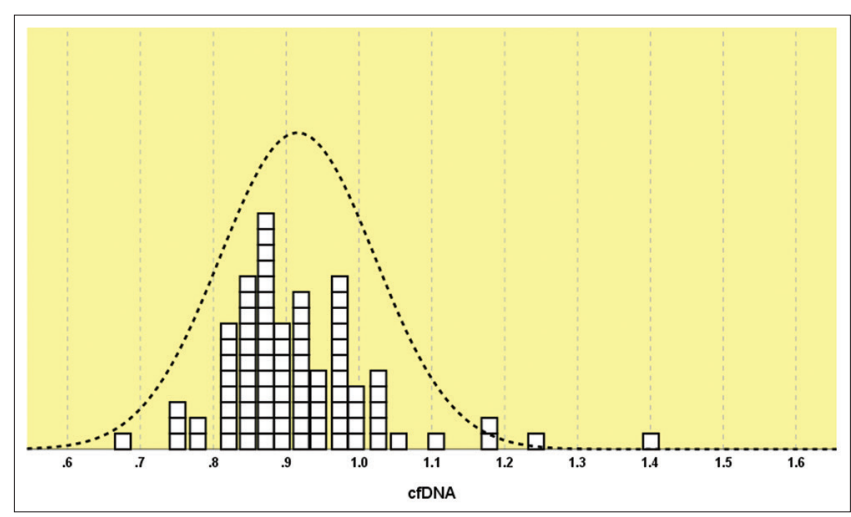

Figure 1: The distributions level of cfDNA in the follicular fluid among participants 
CfDNAlevel in FF was not significantly associated with patients' parameters (Table 2), no statistically significant relations were found; however, we notice that there is a relation between a certain level of cfDNA and women age, for example, higher level of cfDNA in younger women, which may reflect higher cellular activity, but this is statistically not significant, $p=(0.688)$, again the duration of infertility, that is, short duration of infertility associated with the low level of cfDNA (0.849 \pm 0.028$)$; however, this still statistically non-significant with $p=0.450$. There was no association between ovarian reserve status, cause of infertility, and type of protocol used whether its agonist or antagonist: $P=0.588$ with cfDNA level

Table 2: Correlation between cell-free DNA level and different participant parameters

\begin{tabular}{|c|c|c|c|}
\hline \multirow[t]{2}{*}{ Variables } & \multicolumn{2}{|c|}{ cfDNA } & \multirow[t]{2}{*}{$\mathrm{p}$-value } \\
\hline & No & Mean \pm SD & \\
\hline \multicolumn{4}{|l|}{ Wife age (years) } \\
\hline $19-29$ & 38 & $0.926 \pm 0.124$ & \multirow[t]{3}{*}{0.688} \\
\hline $30-39$ & 42 & $0.910 \pm 0.081$ & \\
\hline$\geq 40$ years & 9 & $0.898 \pm 0.135$ & \\
\hline \multicolumn{4}{|l|}{$\mathrm{BMI}\left(\mathrm{kg} / \mathrm{m}^{2}\right)$} \\
\hline Normal (18.5-24.9) & 34 & $0.923 \pm 0.077$ & \multirow[t]{3}{*}{0.626} \\
\hline Overweight (25-29.9) & 47 & $0.916 \pm 0.129$ & \\
\hline Obese $(\geq 30)$ & 8 & $0.883 \pm 0.059$ & \\
\hline \multicolumn{4}{|l|}{ Duration of infertility } \\
\hline$<2$ & 4 & $0.849 \pm 0.028$ & \multirow[t]{3}{*}{0.450} \\
\hline $2-4$ & 27 & $0.919 \pm 0.122$ & \\
\hline$\geq 5$ years & 58 & $0.919 \pm 0.101$ & \\
\hline \multicolumn{4}{|l|}{ Cause of infertility } \\
\hline Endometriosis & 8 & $0.924 \pm 0.069$ & \multirow[t]{8}{*}{0.926} \\
\hline $\begin{array}{l}\text { Hypogonadotropic } \\
\text { hypogonadism }\end{array}$ & 3 & $0.860 \pm 0.177$ & \\
\hline Male & 27 & $0.907 \pm 0.095$ & \\
\hline Mixed & 10 & $0.910 \pm 0.065$ & \\
\hline PCOS & 6 & $0.915 \pm 0.067$ & \\
\hline Poor reserve & 12 & $0.905 \pm 0.134$ & \\
\hline Tubal & 11 & $0.953 \pm 0.084$ & \\
\hline Unexplained & 12 & $0.925 \pm 0.167$ & \\
\hline \multicolumn{4}{|l|}{ First ICSI } \\
\hline Yes & 31 & $0.912 \pm 0.088$ & \multirow[t]{2}{*}{0.821} \\
\hline No & 58 & $0.917 \pm 0.116$ & \\
\hline \multicolumn{4}{|l|}{ Type of protocol } \\
\hline Antagonist & 83 & $0.917 \pm 0.108$ & \multirow[t]{2}{*}{0.588} \\
\hline Agonist & 6 & $0.893 \pm 0.079$ & \\
\hline
\end{tabular}

The study shows non-significant relation between cfDNA and hormonal analysis of participant, the same non-significant relations with AFC; however, analysis shows that a low level of cfDNA associated with a lower number of follicles than with the higher number of follicles cfDNA $=(0.902 \pm 0.103)$ and $(0.922 \pm 0.108)$, respectively, with $p=0.411$.

Figure 2 shows correlations of cfDNA level and several embryos that are available for transfer.

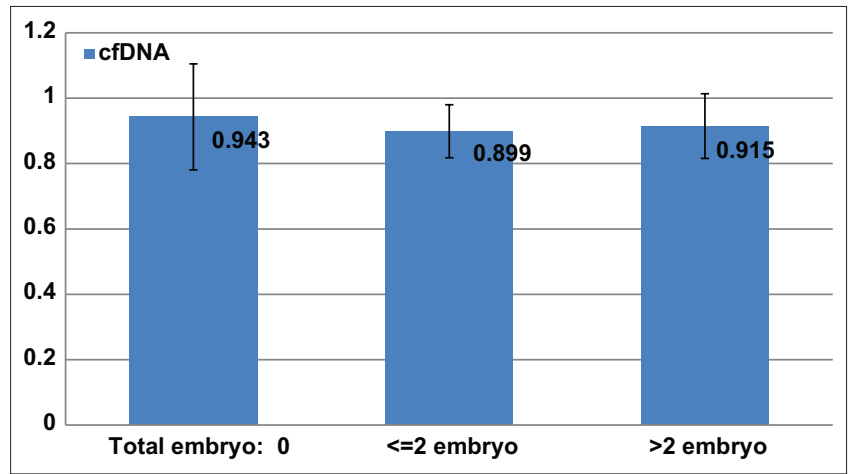

Figure 2: Correlations of cfDNA level and several embryos that are available for transfer
This figure shows the higher level of cfDNA detected when no embryo presents for transfer and also a high level detected with a high number of embryos, but it was non-significant statistically.

Pregnancy rate: There were no significant clear relations between PT test and cfDNA; however, cfDNA was lower in FF of pregnant women than in non-pregnant $(0.900 \pm 0.085$ and $0.912 \pm 0.099)$, respectively, and higher level when we decide to freeze all or when no embryo is present to be transferred, as shown in Table 3.

Table 3: Relationship of cfDNA with patient's hormonal and embryological results

\begin{tabular}{|c|c|c|c|}
\hline \multirow[t]{2}{*}{ Variables of patient } & \multicolumn{2}{|c|}{ cfDNA } & \multirow[t]{2}{*}{$p$-value } \\
\hline & No. & Mean \pm SD & \\
\hline \multicolumn{4}{|l|}{$\overline{F S H}(\mathrm{U} / \mathrm{L})$} \\
\hline$<10$ & 47 & $0.919 \pm 0.093$ & \multirow[t]{2}{*}{0.302} \\
\hline$\geq 10$ & 8 & $0.883 \pm 0.059$ & \\
\hline \multicolumn{4}{|l|}{$\mathrm{LH}(\mathrm{U} / \mathrm{L})$} \\
\hline$<3$ & 8 & $0.892 \pm 0.103$ & \multirow[t]{3}{*}{0.581} \\
\hline $3-5$ & 23 & $0.928 \pm 0.087$ & \\
\hline$>5$ & 23 & $0.915 \pm 0.074$ & \\
\hline \multicolumn{4}{|l|}{ AMH } \\
\hline$\leq 1$ & 26 & $0.905 \pm 0.101$ & \multirow[t]{2}{*}{0.554} \\
\hline$>1$ & 63 & $0.920 \pm 0.109$ & \\
\hline \multicolumn{4}{|l|}{ AFC } \\
\hline$<10$ & 28 & $0.902 \pm 0.103$ & \multirow[t]{2}{*}{0.411} \\
\hline$\geq 10$ & 61 & $0.922 \pm 0.108$ & \\
\hline \multicolumn{4}{|l|}{ Number of oocytes } \\
\hline$\leq 6$ & 25 & $0.921 \pm 0.102$ & \multirow[t]{2}{*}{0.765} \\
\hline$>6$ & 64 & $0.913 \pm 0.109$ & \\
\hline \multicolumn{4}{|c|}{ Total number of embryos } \\
\hline 0 & 13 & $0.943 \pm 0.162$ & \multirow[t]{3}{*}{0.510} \\
\hline$\leq 2$ & 21 & $0.899 \pm 0.081$ & \\
\hline$>2$ & 55 & $0.915 \pm 0.099$ & \\
\hline \multicolumn{4}{|l|}{ Pregnancy test } \\
\hline Positive & 23 & $0.900 \pm 0.085$ & \multirow[t]{4}{*}{0.282} \\
\hline Negative & 55 & $0.912 \pm 0.099$ & \\
\hline Freeze all & 8 & $0.952 \pm 0.187$ & \\
\hline No ET & 3 & $1.010 \pm 0.108$ & \\
\hline \multicolumn{4}{|l|}{ Pregnancy test } \\
\hline Positive & 23 & $0.900 \pm 0.085$ & \multirow[t]{2}{*}{0.613} \\
\hline Negative & 55 & $0.912 \pm 0.099$ & \\
\hline \multicolumn{4}{|l|}{ Frozen E } \\
\hline Yes & 32 & $0.911 \pm 0.123$ & \multirow[t]{2}{*}{0.725} \\
\hline No & 56 & $0.920 \pm 0.097$ & \\
\hline
\end{tabular}

\section{Discussion}

Study shows the reference level of cfDNA in the FF of Iraqi women participated in this study with Mean $\pm S D, 0.916 \pm 0.106 \mathrm{ng} / \mu \mathrm{l}$. There was nonsignificant relationship between cfDNA and patient demographic features such as age, BMI, her hormonal analysis, and laboratory results; however, low level of cfDNA notices in patients with short duration of infertility, $<2$ years, this is may be related to the fact that short duration of infertility is less stressful than long time of infertility [17], [18] (Table 2), same as mentioned in research done on patients undergo an IVF treatment [19], in the same time, this is proved that FF derived from serum and granulosa cell secretions and there is communication between FF and plasma [22]. Czamanski-Cohen et al. mentioned that maternal cell apoptotic leads high level of circulatory cfDNA, may be due that may be create a bad environment for pregnancy, and whether there is a pathological 
process causing elevated cfDNA as well as causing her infertility [5], the same authors show that stress management by relaxation technique reduce plasma cfDNA and improved IVF outcome [23]. Although the level of cfDNA was higher in female infertility factor, whether ovarian or tubal, level not reached statistically significant value, still this value may affect the quantity and quality of oocyte retrieved; two important factors for embryo production and major influence in IVF success, as many authors recognized that FF microenvironment strongly influenced the competence of oocyte development [24], [25]. We think that there is a strong association and specific balance between granulosa cells apoptosis and oocyte development, the granulosa cells have specific programmed cells death that expresses by cfDNA in the FF neither high nor low level of cfDNA is important for oocyte development, this study shows that when we had no embryo to be transferred and when we in forced for freeze all strategy the cfDNA was higher, but the level was not statistically significant may be due to low sample size, FF composition is influenced oocyte quality.

\section{Conclusion}

The present study notices that cfDNA in the FF may mainly reflect the cellular activity and the balance between programed apoptosis and cell necrosis.

\section{Acknowledgment}

Thanks to God for his blessing throughout our research work, many thanks to all embryologists and laboratory workers who participated in this study.

\section{References}

1. Stiligliani S, Massarotti C, Scaruffi P. Pronuclear score improves prediction of embryo implantation success in ICSI cycles. BMC Pregnancy Childbirth. 2021;21(1):361.

2. Scalici E, Traver S, Molinari N, Mullet T. Cell-free DNA in human follicular fluid as a biomarker of embryo quality. Hum Reprod. 2014;29(12):2661. https://doi.org/10.1093/humrep/deu238 PMid:25267787

3. Uyar A, Torrealday S, Seli E. Cumulus and granulosa cell markers of oocyte and embryo quality. Fertil Steril. 2013;99(4):979-97. https://doi.org/10.1016/j.fertnstert.2013.01.129 PMid:23498999

4. Assou S, Haouzi D, De Vos J, Hamamah S. Human cumulus cells as biomarker for embryo and pregnancy outcome. Mol
Hum Reprod. 2010;16(8):531-8. https://doi.org/10.1093/molehr/ gaq032

PMid:20435608

5. Czamanski-Cohen J, Sarid O, Cwikel J. Increased plasma cell-free DNA is associated with low pregnancy rates among women undergoing IVF-embryo transfer. Reprod Biomed Online 2013;26:36-41. https://doi.org/10.1016/j.rbmo.2012.09.018 PMid:23182744

6. Baka S, Malamitisi A, Puchner. Novel follicular fluid factors influencing oocyte developmental potential in IVF: A review. Reprod Biomed. 2006;12(4):500-6. https://doi.org/10.1016/ s1472-6483(10)62005-6

PMid: 16740225

7. Daniel AD, David RM, Mandy GK. Oocyte environment: Follicular fluid and cumulus cells are critical for oocyte health, for oocyte health. Fertil Steril. 2015;103(2):303-16. https://doi. org/10.1016/j.fertnstert.2014.11.015

PMid:25497448

8. Da Broi MG, Giorgi VS, Wang F, Keefe DL. Influence of follicular fluid and cumulus cells on oocyte quality: Clinical implications. J Assist Reprod Genet. 2018;35(5):735-51. https://doi. org/10.1007/s10815-018-1143-3

PMid:29497954

9. Mandel P, Metais P. Nuclear acids in human blood plasma. C R Acad Sci Paris. 1948;142:241-3.

PMid: 18875018

10. Hui L, Maron JL, Gahan PB. Other body fluids as non-invasive source of cell-free DNA/RNA. Adv Predict Prev Pers Med 2015;5:295-323.

11. Pray IA. Discovery of DNA structure and function: Watsone and crick. Nat Educ. 2008;1(1):100.

12. Lo YM, Corbetta N, Chamberlain PF, Rai V, Sargent IT, Redman CW, Wainscoat JS. Presence of fetal DNA in maternal plasma and serum. Lancet. 1997;350:485-7. https://doi. org/10.1016/S0140-6736(97)02174-0 PMid:9274585

13. Liao JW, Gronowski AM. Non invasive prenatal testing using cell-free fetal DNA in maternal circulation. Clin Chim Acta. 2014;428:44-50.

PMid:24482806

14. van Boeckel SR, Davidson DJ, Norman JE, Stock SJ. Cellfree DNA and spontaneous prterm birth. Reproduction. 2018;155(3):137-45. https://doi.org/10.1530/REP-17-0619 PMid:29269517

15. Amaral LM, Sandrium VC, Kutcher ME. Circulating total cellfree DNA levels are increased in hypertensive disorders of pregnancy and associated with prohypertensive factors and adverse clinical outcomes. Int J Mol Sci. 2021;22:564. https:// doi.org/10.3390/ijms22020564 PMid:33429954

16. Lee TJ, Rol DL. Menezes MA. Cell-free fetal DNA testing in singleton IVF conceptions. Hum Reprod. 2018;33(4):572-8. https://doi.org/10.1093/humrep/dey033 PMid:29462319

17. Pedini $P$, Graiet $H$, Laget L. Qualitative and quantitative comparison of cell-free DNA and cell-free fetal DNA isolation by four (semi-)automated extraction methods: Impact in two clinical applications: Chimerism quantification and noninvasive prenatal diagnosis. J Transl Med. 2021;19:15.

18. Jiang N, Reich CF $3^{\text {rd }}$, Pisetsky DS. Role of macrophages in the generation of circulating nucleosomes from dead and dying cells. Blood. 2003;102(6):2243-50. https://doi.org/10.1182/ blood-2002-10-3312

PMid:12775567 
19. Grabusching S, Jacobous A, Holdenrieder S. Putative origins of cell-free DNA in humans: A review of active and passive nucleic acid release mechanisms. Int J Mol Sci. 2020;21(21):8062. https://doi.org/10.3390/ijms21218062

PMid:33137955

20. Hengartner MO. The biochemistry of apoptosis. J Nat. 2000;407(6805):770-6. https://doi.org/10.1038/35037710

PMid: 11048727

21. Naoyuki Umetani N, Kim J, Hiramatsu S, Reber HA, Hines OJ Bilchik JA. Increased integrity of free circulating DNA in sera of patients with colorectal or periampullary cancer: Direct quantitative PCR for ALU repeats. Clin Chem. 2006;52:1062-9. https://doi.org/10.1373/clinchem.2006.068577

PMid:16723681

22. Rodgers RJ, Iriving-Rodgers HF. Formation of ovarian follicular antrum and follicular fluid. Biol Reprod. 2010;82(6):1021-9. https://doi.org/10.1095/biolreprod.109.082941

PMid:20164441

23. Czamanski-Cohen J, Sarid O, Cwikel J. Decrease in cell free DNA levels following participation in stress reduction techniques among women undergoing infertility treatment. Arch Womens Ment Health. 2014;17(3):251-3. https://doi.org/10.1007/ s00737-013-0407-2

PMid:24420416

24. Mendoza C, Ruiz-Requena E, Ortega E. Follicular fluid markers of oocyte developmental potential. Hum Reprod. 2002;17:1017-22.

25. Sabine T, Elodie S, Tiffany M. Cell-free DNA in human follicular microenvironment: New prognostic biomarker to predict in vitro fertilization outcomes. PLoS One J. 2015;10(8):1371. https:// doi.org/10.1371/journal.pone.0136172

PMid:26288130 